Emir. J. Agric. Sci. 2004. 16 (2): 09-17

http://www.cfs.uaeu.ac.ae/research/ejas.html

\title{
Response of some turfgrasses to salinity and environmental conditions of Saudi Arabia.
}

\author{
Nasser S. Al-Khalifah \\ Natural Resources and Environmental Research Institute, King \\ Abdulaziz City for Science and Technology, Saudi Arabia
}

\begin{abstract}
Growth and performance of 2 Zoysiagrass cultivars ('Miyako', 'Nagissa'), 2 Bermudagrass hybrid cultivars ('Tifway', 'Tifgreen') and 1 St. Augustinegrass cultivar ('Floratam') were evaluated with two salinity levels $\left(4.6\right.$ and $\left.10.27 \mathrm{dSm}^{-1}\right)$ of irrigation water in greenhouse and field conditions of Saudi Arabia. The goal of the study was to select the most suitable cultivars for each condition. The experimental design was a randomized complete block design (RCBD) with four replicates. In order to evaluate the effect of salinity and different type of environmental conditions on turfgrass growth parameters such as coverage, color and quality of the turf, fresh and dry biomass were determined at monthly intervals. In addition, variations of the chlorophyll content between cultivars at different salinity levels were also studied. Turfgrass cultivars exhibited different growth behavior in response to the various treatments. Bermudagrass cultivars, especially 'Tifway', appeared to tolerate saline irrigation water and the increased salt concentration in the soil. 'Tifway' produced a significantly higher amount of biomass with high salinity irrigation under greenhouse conditions. Leaflength of 'Miyako' and 'Nagissa' was not affected by the salinity irrigation but there was a significant difference concerning the influence of shading. The St. Augustinegrass cultivar 'Floratam' produced a significantly lower amount of chlorophyll with high salinity irrigation under shading but it produced a considerable amount of chlorophyll when the salinity level was lowered under the greenhouse conditions. Bermudagrass demonstrated the best color throughout the year, while Zoysiagrass and St. Augustinegrass developed yellowish colors under shade.
\end{abstract}

Key words: Bermuda, chlorophyll, Floratam, irrigation, St. Augustine, Zoysia.

\section{الستجلبة بهض أنواع المصلحلت الخضراء للملوحة والاجهادك البيئية بالمماكة العربة السعونية i نامر بن صالح الخلفة}

معهد بحوث الموارد اللابيعية والبيئة، مدينة الملك عبد العزبز للعلوم والقنية، المماكة العربية للسعوية

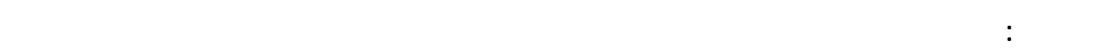

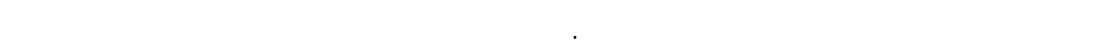
(Bermudagrass) هوعين (Zoysiagrass)

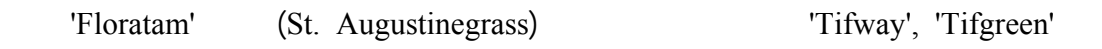

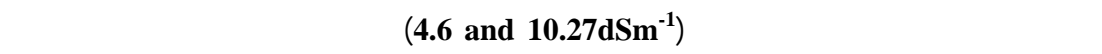

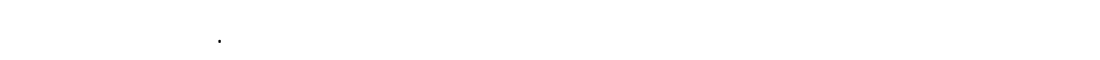

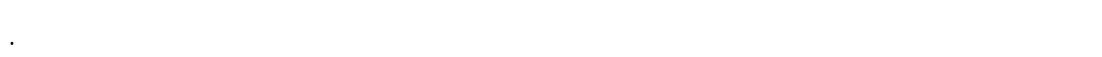

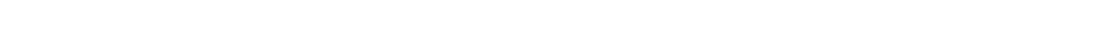

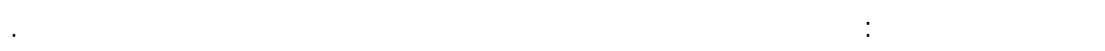

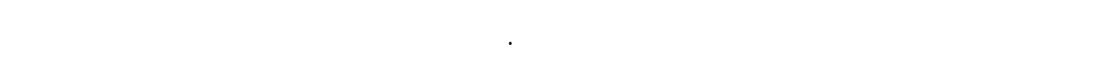

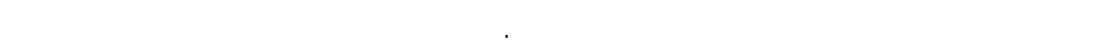

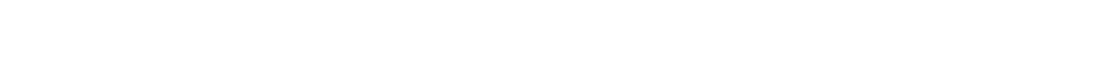
تحطل افضل لنيجل زيوسيا.

كاملتففتلحية: برمودا، كلوروفيل، ري، النجل الفرنسي، النجل اليابلني 


\section{Introduction}

Maintaining good quality turf in an arid region is a difficult task and people are searching for turfgrass species or cultivars that will perform well in harsh desert environmental conditions. A dense turf could contribute to environmental improvement through the reduction of solar radiation intensity associated with the sunny climate of deserts. Availability of good quality irrigation water is always a constraint in the arid regions and the water desalination is an expensive alternative. In addition, due to the increased pumping of saline water from the deep wells the level of total salinity in the soils has increased. The detrimental effects of salinity on turfgrass growth include osmotic stress, ion toxicity and nutritional disturbances (Cheesman, 1988). Salt tolerant plants have the ability to minimize these detrimental effects by producing series of anatomical, morphological and physiological adaptations (Poljakoff- Mayber, 1975) such as an extensive root system and salt secreting glands on the leaf surface (Marcum et al., 1998). Salt-tolerant turfgrass species and cultivars are, therefore, valuable for maintaining grass cover in the saline areas (Dudeck and Peacock, 1984). Turfgrass species and cultivars differ in their tolerance to salinity, and this is more pronounced among Bermudagrass hybrids and cultivars. Variations in salt tolerance among turfgrasses have been demonstrated in many studies using hydroponic culture systems (Qian et al., 2000, 2001; Al-Shammary et al., 2004).

Extreme aridity in the region and fluctuating climatic conditions are some of the limiting factors for the selection of suitable species or cultivars of turfgrass management in Saudi Arabia. During the winter season
(November-January) the mean maximum temperature drops to $5-20^{\circ} \mathrm{C}$ while during the summer season (MaySeptember) the maximum mean temperature ranges between 30 and $45^{\circ} \mathrm{C}$. The relative humidity of the region is also low during the summer period.

Despite these adverse conditions, the demand for greening is increasing in Saudi Arabia (Okawara et al., 2003). To achieve this task, there is a need for proper selection of suitable turfgrass cultivars, which can provide adequate growth and quality in the arid climate especially when saline irrigation water is used. However, the need for salt tolerant grasses has became very important due to the limited supply of irrigation water and the high salinity of the ground water (Al-Khalifah et al., 1993). Since the turf has to undergo two climatic extremes, the average performance of turfgrass, in terms of quality, texture and color throughout the year may be an appropriate criterion for selecting a species or a cultivar for the desert environment.

The objectives of this study were to compare the growth and quality of 5 turfgrass cultivars under two water salinity levels, in greenhouse and field conditions of arid region.

\section{Materials and Methods}

This study was conducted at Riyadh, the central region of Saudi Arabia where the Natural Resources and Environmental Research Institute of King Abdulaziz City for Science and Technology is situated. Five cultivars of warm season turfgrasses were procured from various sources (Table-1). Tillers of 'Miyako', 'Nagissa' (Zoysia matrella (L.) Merr.), 'Tifway', 'Tifgreen' (Cynodon dactylonL.x C. transvaalensis Burtt.-Davy) and 'Floratam' (Stenotaphrum secundatum (Walt.) Kunze) were planted in 
polystyrene pots of $270 \mathrm{~mm}$ diameter and $300 \mathrm{~mm}$ height. In order to provide uniform soil conditions all the pots were filled with a mixture of sandy loam and peat moss $(3: 1, \mathrm{v} / \mathrm{v})$. Fifteen sprigs of ca.70mm height were planted vertically in each pot. All the pots were kept inside the greenhouse for a period of one month for initial establishment, and later on the grass was cut uniformly at around $50 \mathrm{~mm}$ height above the pots. The pots were arranged in a randomized complete block design (RCBD) with four replicates. Temperatures inside the greenhouse and outside were recorded three times daily at $6 \mathrm{am}, 12$ noon and $6 \mathrm{pm}$. Mean monthly temperatures for the study period, January to December 2003 are presented in Table 2.

Table 1. Name and source of turfgrass cultivars.

\begin{tabular}{llll} 
Sl. No. & Name of species & Name of cultivar & \multicolumn{1}{c}{ Source } \\
\hline 1 & Zoysia matrella & 'Miyako' & $\begin{array}{l}\text { Saudi-Japan Research project } \\
\text { Saudi-Japan project }\end{array}$ \\
3 & $\begin{array}{l}\text { Zoysia matrella } \\
\text { Cynodon dactylon } x \\
\text { C. transvaalensis }\end{array}$ & 'Nagissa' & 'Tifway Bermuda' \\
& $\begin{array}{l}\text { Southern Turf Nurseries, } \\
\text { Georgia, USA }\end{array}$ \\
4 & $\begin{array}{l}\text { Cynodon dactylon } x \\
\text { C. transvaalensis }\end{array}$ & 'Tifgreen Bermuda' & $\begin{array}{l}\text { Southern Turf Nurseries, } \\
\text { Georgia, USA }\end{array}$ \\
5 & Stenotepharum secundatum & 'Floratam' & Saudi International Airports Proj. \\
\hline
\end{tabular}

One set of pots was exposed to sunlight and the other set remined in the greenhouse with temperatures ranging between $28^{\circ} \mathrm{C}$ during day-time and $15^{\circ} \mathrm{C}$ in the night-time with a photoperiod of $14 \mathrm{~h}$. Depending on the incident radiation, the light intensity on a horizontal plane just above the canopy at 12:00 AM averaged up to $352 \mu \mathrm{molm}^{-2} \mathrm{~s}^{-1}$, whereas average light intensity outside the green house was recorded as $1526 \mu \mathrm{molm}^{-2} \mathrm{~s}^{-1}$. The pots inside the greenhouse were divided into two groups. One group was irrigated daily with $1000 \mathrm{ml}$ of saline water to each pot, with an electrical conductivity of $10.27 \mathrm{dSm}^{-1}$, and the other set was treated with an equal amount of low salinity water with $\mathrm{EC}=$ $4.6 \mathrm{dSm}^{-1}$. The low salinity irrigation was used as control since irrigation water with $4-5 \mathrm{dSm}^{-1}$ is the lowest EC that is used by the farmers for the agriculture management in the adjacent location of the study area.

Table 2. Mean monthly temperature $\left({ }^{\circ} \mathrm{C}\right)$ for the study period, January to December 2003.

\begin{tabular}{lcccccccccccc}
\hline & Jan. & Feb. & Mar. Apr. May & Jun. & Jul. & Aug. & Sept. Oct. & Nov. Dec. \\
\hline $\begin{array}{l}\text { Green } \\
\text { house }\end{array}$ & 17.0 & 18.5 & 21.0 & 22.8 & 30.5 & 27.1 & 28.0 & 29.0 & 29.0 & 25.7 & 22.7 & 19.9 \\
$\begin{array}{l}\text { Outside } \\
15.2\end{array}$ & 17.7 & 22.1 & 26.6 & 33.6 & 34.5 & 37.3 & 35.3 & 32.5 & 27.4 & 21.4 & 16.8 \\
\hline
\end{tabular}

Pots exposed to direct sunlight were also given equal amounts of low salinity water $\left(\mathrm{EC}=4.6 \mathrm{dSm}^{-1}\right)$ at the same frequency. Saline water was pumped directly from the deep well (150 $\mathrm{m}$ depth) and the low salinity water was prepared through reverse osmosis. Water samples were analyzed for $\mathrm{pH}$, total dissolved salts, electrical conductivity, and total alkalinity as $\mathrm{CaCO}_{3} \mathrm{mgL}^{-1}$ and total hardness as $\mathrm{CaCO}_{3} \mathrm{mgL}^{-1}$. Chemical composition of irrigation water is provided in Table 3. The physical and chemical 
properties of the potting medium were analyzed before the commencement of experiment and was found to be an electrical conductivity of $3.4 \mathrm{dSm}^{-1}, \mathrm{pH}$ 7.1, total hardness $1128 \mathrm{mg} \mathrm{L}^{-1}$ and sodium absorption ratio 3.2. Soil samples were also collected from each pot at the end of the experiment for determination of $\mathrm{pH}, \mathrm{EC}$ of the saturated soil extract, Sodium Absorption Ratio (SAR) and total hardness (Table 4).

Table 3. Physical and chemical qualities of the irrigation water.

\begin{tabular}{lcccccc}
\hline Samples & $\begin{array}{l}\text { EC } \\
\left(\mathbf{d S m}^{-\mathbf{1}}\right)\end{array}$ & $\mathbf{p H}$ & $\begin{array}{l}\text { TDS } \\
\left(\mathbf{m g L}^{-\mathbf{1}}\right)\end{array}$ & SAR & $\begin{array}{l}\text { Total Alkalinity } \\
\mathbf{a s}_{\mathbf{C a C O}}\left(\mathbf{m g L}^{-1}\right)\end{array}$ & $\begin{array}{l}\text { Total Hardness } \\
\text { as }_{\mathbf{C a C O}}\left(\mathbf{m g L}^{-\mathbf{1}}\right)\end{array}$ \\
\hline High Salinity & 10.3 & 8.0 & 6573 & 8.12 & 102 & 3886 \\
Low salinity & 4.6 & 8.3 & 2944 & 3.86 & 103 & 1484 \\
\hline
\end{tabular}

Table 4. Analysis of the saturated soil extracts collected from the pots at the end of the experiment.

\begin{tabular}{llcccc}
\hline Cultivars & Conditions & $\mathbf{E C}\left(\mathbf{d S m}^{-\mathbf{1}}\right)$ & $\mathbf{p H}$ & Total Hardness $\left.\mathbf{( m g L}^{-\mathbf{1}}\right)$ & SAR \\
\hline \multirow{2}{*}{ 'Miyako' } & Low salinity & 5.0 & 7.8 & 1517 & 5.9 \\
& High salinity & 12.9 & 8.1 & 5416 & 7.7 \\
\multirow{2}{*}{ 'Nagissa' } & Low salinity & 4.6 & 7.8 & 1480 & 5.1 \\
& High salinity & 11.6 & 7.8 & 4563 & 6.4 \\
& & & & & 5.2 \\
'Tifway' & Low salinity & 4.9 & 8.2 & 1663 & 7.4 \\
& High salinity & 13.6 & 8.1 & 5416 & \\
\multirow{5}{*}{ 'Tifgreen' } & Low salinity & 5.00 & 8.0 & 1685 & 5.3 \\
& High salinity & 10.4 & 8.0 & 4120 & 5.9 \\
'Floratam' & Low salinity & 5.3 & 8.2 & 1690 & 5.4 \\
& High salinity & 11.7 & 8.1 & 5324 & 7.5 \\
& & & & & \\
\hline
\end{tabular}

LSD (0.05) for (Electrical Conductivity: low salinity $0.68 \&$ high salinity 1.74$)$; (pH: low salinity $0.45 \&$ high salinity 0.48 ); Total Hardness (low salinity $82.6 \&$ high salinity 68.4 ); SAR (low salinity $0.56 \&$ high salinity 0.73 )

The aerial portion of grasses $50 \mathrm{~mm}$ above ground level was clipped off every month using a sharp cutter, collected and weighed. Plant samples were oven-dried at $70^{\circ} \mathrm{C}$ for $72 \mathrm{~h}$. and dry-matter content was determined. Leaf samples were also collected from each cultivar under different treatments for chlorophyll analysis according to Moran (1982). One hundred milligrams of finely cut leaf samples were dipped in $10 \mathrm{ml}$ of $N, N$ Dimethylformamide and kept in a dark refrigerator at $4^{\circ} \mathrm{C}$ for 48 hours. The filtered samples were analyzed for total chlorophyll content using a spectrophotometer (Spectronic 20D+) (Table 5). Photometric determination was made by using the absorbance at $652 \mathrm{~nm}$ and reported as milligrams per gram of fresh-weight as suggested by Wilkinson and Beard (1974). 
Emir. J. Agric. Sci. 2004. 16 (2): 09-17

http://www.cfs.uaeu.ac.ae/research/ejas.html

Table 5. Mean fresh-weight, dry-weight and chlorophyll content of five turfgrass cultivars.

\begin{tabular}{|c|c|c|c|c|c|c|c|c|c|}
\hline Cultivars & $\begin{array}{l}\text { Fresl } \\
\text { lg/po }\end{array}$ & $\begin{array}{l}\text { 1-weigh } \\
\text { t) }\end{array}$ & & $\begin{array}{l}\text { Dry-w } \\
\text { (g/pot) }\end{array}$ & eight & & $\begin{array}{l}\text { Chloro } \\
\text { conten }\end{array}$ & $\begin{array}{l}\text { hyll } \\
(\mathrm{mg} / \mathrm{g})\end{array}$ & \\
\hline & hsgh & lsgh & Isop & hsgh & Isgh & Isop & hsgh & Isgh & lsop \\
\hline 'Miyako' & 28.0 & 42.4 & 17.1 & 10.8 & 14.7 & 6.6 & 2.4 & 2.9 & 2.4 \\
\hline 'Nagissa' & 39.9 & 70.6 & 16.8 & 15.6 & 23.8 & 6.7 & 2.2 & 2.7 & 2.3 \\
\hline 'Tifway' & 49.7 & 34.1 & 15.6 & 20.2 & 12.3 & 6.2 & 1.8 & 2.6 & 2.6 \\
\hline 'Tifgreen' & 33.4 & 65.9 & 23.6 & 10.8 & 23.0 & 7.9 & 3.0 & 3.0 & 2.4 \\
\hline 'Floratam' & 67.1 & 139.7 & 107.6 & 12.9 & 23.3 & 27.5 & 1.0 & 2.1 & 1.8 \\
\hline $\operatorname{LSD}(0.05)$ & & & & & 5.4 & & & 0.8 & \\
\hline
\end{tabular}

Hsgh= high salinity and greenhouse; $1 \mathrm{sgh}=$ low salinity and green house, $1 \mathrm{sop}=10 \mathrm{w}$ salinity and open field.

Turf performance, including quality, coverage and color was evaluated visually on a monthly basis. Turf quality was evaluated monthly a using 0-9 scale, where 0 was poor, 1-5 was least acceptable, 6-8 was the acceptable level and 9 was the best. Plant coverage, rated as a percentage of recovery after each clipping, was evaluated on a $0-9$ scale, where 0 means no recovery, 5 means $50 \%$ recovery and 9 means a recovery of more than $90 \%$. Mean visual quality, coverage and color are provided in Table-6.

Table 6. Mean visual quality, coverage and color of five turfgrasses cultivars under salinity and environmental conditions.

\begin{tabular}{llllllllll}
\hline Cultivars & \multicolumn{3}{c}{ Turf quality } & \multicolumn{5}{c}{ Turf coverage } & \multicolumn{2}{c}{ Color } \\
& hsgh & Lsgh & lsop & hsgh & lsgh & lsop & hsgh & lsgh & lsop \\
\hline 'Miyako' & 6.0 & 7.5 & 7.0 & 7.0 & 7.8 & 6.8 & 6.7 & 7.2 & 5.3 \\
'Nagissa' & 5.8 & 8.7 & 6.9 & 6.2 & 8.3 & 7.0 & 5.3 & 7.2 & 6.1 \\
'Tifway' & 7.5 & 4.0 & 4.8 & 8.2 & 4.5 & 5.1 & 7.5 & 4.8 & 4.7 \\
'Tifgreen' & 5.5 & 6.5 & 7.8 & 5.7 & 6.8 & 7.1 & 4.3 & 6.8 & 6.7 \\
'Floratam' & 5.5 & 7.8 & 8.0 & 6.6 & 8.7 & 6.5 & 4.7 & 8.0 & 7.1 \\
LSD (0.05) & & 2.3 & & & 2.4 & & & 2.1 & \\
-
\end{tabular}

Hsgh= high salinity and greenhouse; $1 \mathrm{sgh}=$ low salinity and green house, $1 \mathrm{sop}=$ low salinity and open field.

The third leaf from the apex of ten randomly selected plants was detached from each pot and its length was measured. Plants were excavated from polystyrene containers and the roots of each plant were gently washed under tap water. The length of the randomly selected 30 roots was measured using a centimeter scale. Mean leaf length and mean root length of the turfgrasses under different treatments are presented in Fig. 1 and Fig. 2 respectively. Data were analyzed statistically by analysis of variance and least significant difference (LSD) according to the method described by Snedecor and Cochran (1973). 


\section{Results and Discussion}

Under controlled conditions and with low saline water, all cultivars except 'Tifway' performed above average in quality, coverage and color (Table 4). The performance of 'Tifway' under high salinity $\left(\mathrm{EC}=10.27 \mathrm{dSm}^{-1}\right)$ and low temperature $\left(27^{\circ} \mathrm{C} / 15^{\circ} \mathrm{C}\right)$ conditions was improved when compared with low salinity $(\mathrm{EC}=4.6$ $\mathrm{dSm}^{-1}$ ) water treatments. Dry-weight content of all cultivars except 'Tifway' was significantly highes in the greenhouse receiving low salinity irrigation and decreased considerably with high salinity watering and further decreased in the outside high temperature, even though irrigated with low salinity water. In the case of 'Tifway', dry-matter content was significantly highes in the highly saline water treatment under greenhouse conditions, showing its high adaptability to the high salinity conditions. The general performance of 'Tifway' can be summarized as high salinity and shade $>$ low salinity and shade $>$ low salinity outside. Francois (1988) studied the effect of salinity on Bermudagrass cultivars and reported that relative top growth of 'Tifton-10', 'Tifway II' and 'Tifton-86 was unaffected by soil salinity until the EC exceeded 2.7, 8.4, and $10.3 \mathrm{dSm}^{-1}$ respectively. This study indicated that under controlled greenhouse conditions, even when irrigated with high salinity water $\left(\mathrm{EC}=10.27 \mathrm{dSm}^{-1}\right)$, fresh- and dry-weight content, quality and coverage of 'Tifway' increased considerably while the quality and biomass yield (dry matter) of the other four cultivars decreased with high salinity irrigation when compared to their respective low salinity conditions.

Among the two Bermudagrasses, 'Tifway' showed increased biomass production under saline conditions compared with 'Tifgreen'. Overall performance of 'Tifgreen' was above average in the open area with low salinity water, which suggested that it can be preferred for the non saline areas and 'Tifway' can be selected for saline areas especially if moderate shade is provided. Both cultivars of Zoysia species exhibited differences in the fresh-weight, dry-weight and chlorophyll content between treatments. However, the cultivar 'Nagissa' showed remarkable decrease in the fresh- and dry-weight content when treated with saline water. The performance of 'Nagissa' in the open condition was above the minimum acceptable level and its fine texture, compact growth and dark green color makes it preferable to 'Miyako' in Saudi Arabia, wherever low salinity water is available.

The chlorophyll content, and fresh- and dry-weight of St. Augustinegrass cultivar 'Flortam' decreased considerably in the saline water, but its performance in the open area was above average with low salinity water irrigation. However, during the winter period, the leaves were yellowish and dried out, which indicated that its use should be limited to the low salinity areas.

'Miyako' and 'Nagissa' showed no significant difference in the mean leaf length between high salinity greenhouse and low salinity irrigation, but there was significant difference concerning the influence of shading (Fig.1). Both Bermudagrasses were significantly affected by the saline water irrigation with little influence of shading. Leaf length of 'Floratam' was not affected either by salinity or by shading. 


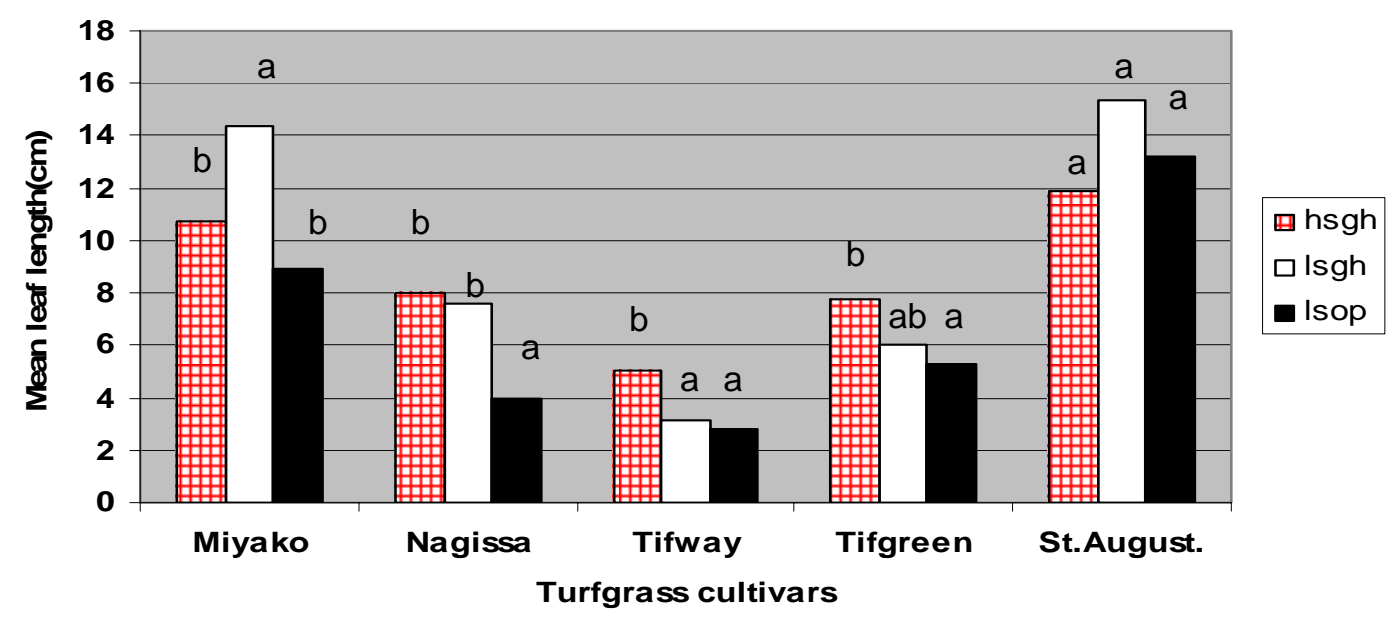

Fig.1. Mean leaf length of different turfgrass cultivars as affected by water salinity. (LSD among treatments at $0.05: 3.9 ; 2.2,1.2,2.1,4.3$ respectively; bars having similar superscript are not significant). hsgh: high salinity and greenhouse; lsgh: low salinity and green house, lsop: low salinity and open field.

Mean root length showed variation among cultivars and between treatments (Fig.2). 'Miyako', 'Tifgreen' and "Floratam" provided bigger root length in high salinity treatments $\left(\mathrm{EC}=10.27 \mathrm{dSm}^{-1}\right)$, but the difference was not significant compared with low salinity water treatments $\left(\mathrm{EC}=4.6 \mathrm{dSm}^{-}\right.$ $\left.{ }^{1}\right)$. Therefore, the two salinity levels of irrigation water did not affect the root length under greenhouse conditions. The mean root length of all cultivars was significantly affected by shading, except for 'Tifway'. In table 3, the results of soil paste extract analysis were compared with the mean root length of all cultivars (Fig. 2). It was observed that increases in Sodium Absorption Ratio above 7 produced longer roots than the respective low salinity water treatments for the cultivars like 'Miyako', 'Tifgreen' and "Floratam".

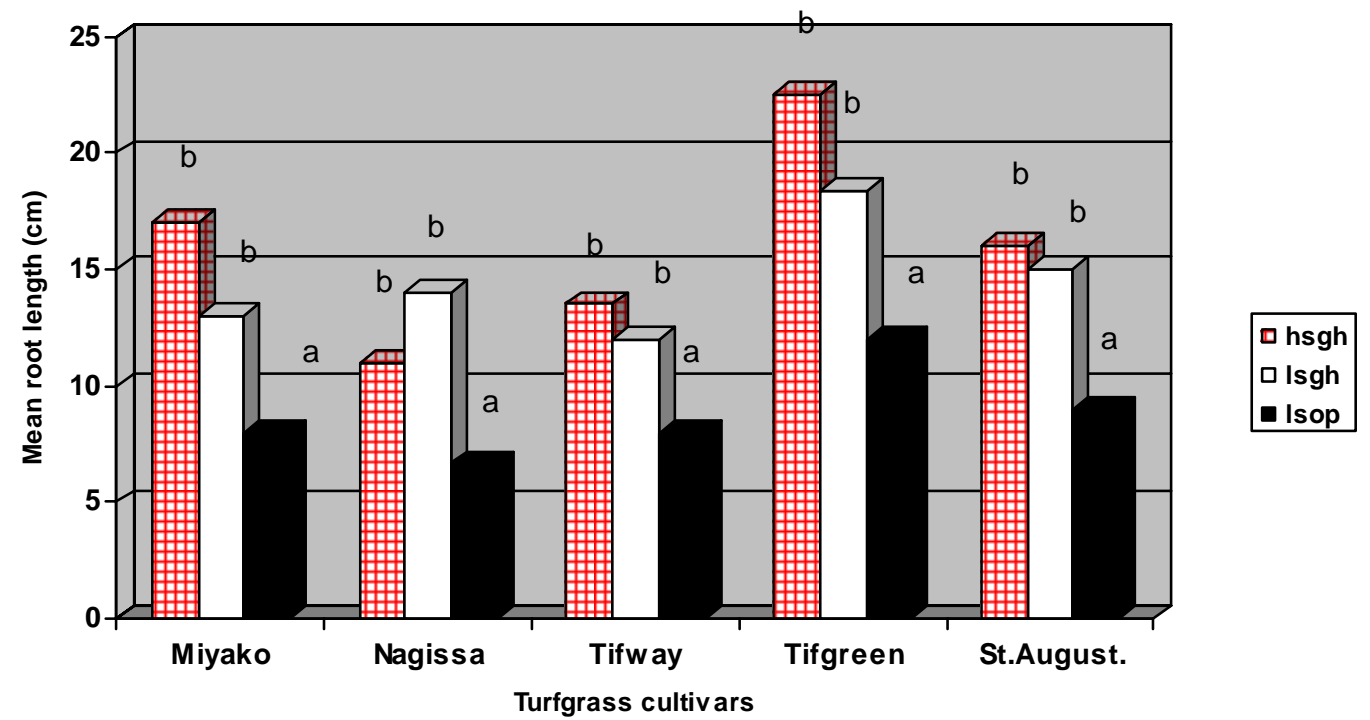

Fig. 2. Mean root length of different turfgrass cultivars as affected by water salinity. (LSD among treatments at $0.05: 4.4,3.6,3.7,5.8,5.5$ respectively; bars having similar superscript are not significant). hsgh: high salinity and greenhouse; lsgh: low salinity and green house, lsop: low salinity and open field. 
In conclusion, among the five turfgrasses tested, only 'Tifway' performed well in highly saline conditions $\quad\left(\mathrm{EC}=10.27 \quad \mathrm{dSm}^{-1}\right)$. 'Nagissa', 'Miyako' and 'Tifgreen' exhibited above average performance in the open field when they were irrigated with low salinity water. "Floratam" color degraded under greenhouse conditions, but performed well in the open field, especially during summer. The results provided an indication of the adaptation and tolerance of the tested cultivars of turfgrasses to irrigation water salinity and the arid environmental conditions of Saudi Arabia.

\section{Acknowledgements}

Thanks are due to King Abdulaziz City for Science and Technology, Riyadh, Saudi Arabia for granting all facilities for the study. Thanks also extended to Dr. A. E. Shanavaskhan. For his assistance throughout the study.

\section{References}

Al-Khalifah, N., F. Al-Mana and T. El-Kiey. 1993. Growth response of selected warm-season turfgrasses to salinity. J. King Abdulaziz Univ.: Met. Env. Arid Land Agric. Sci. 4:21-30.

Al-Shammary, S. F., Y. L. Qian and S. J. Wallner. 2004. Growth responses of four turfgrass species to salinity. Agricultural Water Management 66:97-111.

Cheeseman, J. M. 1988. Mechanisms of salinity tolerance in plants. Plant Physiol. 87:745-755.

Dudeck, A. E. and C. H. Peacock. 1984. Effects of salinity on seashore paspalum turfgrass. Agron. J. 77: 47-50.

Francois, L. E. 1988. Salinity effect on three turf Bermudagrasses. Hortscience 23(4): 706-708.

Marcum, K. B., S. J. Anderson and M. C. Engelke. 1998. Salt gland ion secretion: a salinity tolerance mechanism among five Zoysiagrass species. Crop Sci.38:806-810.

Moran, R. 1982. Formulae for determination of Chlorophyllous pigments extracted with $\mathrm{N}, \mathrm{N}$ Dimethylformamide. Plant physiology 9:1376-1381.

Okawara, R., T. Ohumura and N. AlKhalifah. 2003. The response of Zoysiagrasses and other grasses to environmental condition of coastal regions in Saudi Arabia. J. Japan. Soc. Turfgrass Sci. 31(2):121-127.

Poljakoff-Mayber, A. 1988. Morphological and anatomical changes in plants as a response to salinity stress. In: PoljakoffMayber, A. and J. Gale (eds). Plants in Saline Environment. Ecological studies 15. Springer, Berlin. Pp97117.

Snedecor, G. W. and W. G. Cochran. 1973. Statistical Methods ( $6^{\text {th }}$ Edn.). Ames, Iowa. USA: Iowa state University Press. pp 305.

Qian, Y. L., M. C. Engelke and M. J. V. Foster. 2000. Salinity effects on Zoysiagrass cultivars and experimental lines. Crop Sci. 40:488-492.

Qian, Y. L., S. J. Wilhem and K. B. Marcum. 2001. Comparative responses of two Kentucky 
Emir. J. Agric. Sci. 2004. 16 (2): 09-17

http://www.cfs.uaeu.ac.ae/research/ejas.html

bluegrass cultivars to salinity stress. Crop Sci. 41:1890-1895.

Wilkinson, J. F. and J. B. Beard. 1974. Morphological responses of Poa pratensis and Festuca rubra to reduced light intensity. In: Roberts, E. C. (ed.) Proc. $2^{\text {nd }}$ Int. Turfgrass Res. Conf. Amer. Soc. Agron., Madison, WI. U.S.A 